\title{
Synthesis and Anticancer Effect of 3,4,5-N-Alkyl-Benzamides on Colon Carcinoma HCT- 116 Cells
}

\author{
JILLY OCTARIA TAGORE CHAN ${ }^{1}$, ADE ARSIANTII,3,*, MAURIN MARCELIA ${ }^{1}$, \\ STEVANO JULIO WIJOYO', FADILAH FADILAH ${ }^{2,3}$, RISTA PUTRIANINGSIH ${ }^{2}$, \\ NORMA NUR AZIZAH ${ }^{3}$, HIROKI TANIMOTO ${ }^{4}$ and KIYOMI KAKIUCHI ${ }^{4}$
}

${ }^{1}$ Medical Student, Faculty of Medicine University of Indonesia, Indonesia.

${ }^{2}$ Department of Medical Chemistry, Faculty of Medicine, University of Indonesia, Indonesia.

${ }^{3}$ Drug Development Research Cluster, Indonesia Medical Education and Research Institute (IMERI),

Faculty of Medicine, University of Indonesia, Jalan Salemba Raya 6 Jakarta 10430, Indonesia, Indonesia.

${ }^{4}$ Graduate School of Materials Science, Nara Institute of Science and Technology (NAIST), 8916-5

Takayama-cho, Ikoma, Nara, Japan.

*Corresponding author E-mail: arsi_ade2002@yahoo.com

http://dx.doi.org/10.13005/ojc/340323

(Received: April 02, 2018; Accepted: May 04, 2018)

\begin{abstract}
The natural phenolic gallic acid has demonstrated a significant inhibition of cell proliferation in a series of cancer cell lines, as well as induced apoptosis in HCT-116 colon cancer cells. This research aims to synthesize six compounds of 3,4,5-trihydroxy-N-alkyl-benzamide derivatives of gallic acid, and investigate its anticancer effect on colon carcinoma HCT-116 cells. Six compounds of 3,4,5-trihydroxy-N-alkyl-benzamide, namely 3,4,5-trihydroxy-N-methyl-benzamide (2); 3,4,5-trihydroxy-N-ethyl-benzamide (3); 3,4,5-trihydroxy-N-butyl-benzamide (4); 3,4,5-trihydroxy$\mathrm{N}$-sec-butyl-benzamide (5); 3,4,5-trihydroxy-N-tert-butyl-benzamide (6) and 3,4,5-trihydroxy-Nhexyl-benzamide (7), have been successfully synthesized by amidation of carboxyl group of gallic acid with six corresponding alkylamines, respectively. Furthermore, anticancer effect of these six synthesized derivatives on colon HCT-116 cells were examined by MTT assay. Data were analyzed by linear regression method to generate $I C_{50}$ value. The results will be compared with gallic acid as an original compound and doxorubicine as a positive control.Amidation of gallic acid with six corresponding alkylamines gave desired -N-methyl-, -N-ethyl-, -N-butyl-, - N-sec-butyl-, $-\mathrm{N}$-ters-butyl-, and $-\mathrm{N}$-hexyl benzamide with yield ranging from $18 \%$ to $84 \%$. Compared to gallic acid $\left(\mathrm{IC}_{50}: 0.05 \mu \mathrm{M}\right)$ and doxorubicine $\left(\mathrm{IC}_{50}: 0.001 \mu \mathrm{M}\right)$, all these six synthesized derivatives showed a lower anticancer effect on colon $\mathrm{HCT}-116$ cells. The strongest anticancer and inhibitory effect on HCT-116 cells has shown by 3,4,5-trihydroxy-N-hexyl benzamide (7) with $\mathrm{IC}_{50}$ value of $0.07 \mu \mathrm{M}$. Our results suggested that 3,4,5-trihydroxy- $\mathrm{N}$-hexyl benzamide (7) is a potential to be developed as a promising anti-colon cancer agent.
\end{abstract}

Keywords: Synthesis, Anticancer, Gallic acid, 3,4,5-trihydroxy-N-alkyl-benzamide, HCT-116 cells.

This is an Open Access article licensed under a Creative Commons Attribution-Non Commercial-Share Alike 4.0 International License (https://creativecommons.org/licenses/by-nc-sa/4.0/), which permits unrestricted Non Commercial use, distribution and reproduction in any medium, provided the original work is properly cited. 


\section{INTRODUCTION}

When benign adenomas and polyps transform into malignancies, colorectal cancer is brought about. It is the 3rd most frequently diagnosed cancer and the $4^{\text {th }}$ most common cause of cancer death worldwide. ${ }^{1}$ According to GLOBOCAN 2012 from the International Agency for Research on Cancer (IARC), the incidence of colorectal cancer in people of both genders was 1,360,602 (9.7\%) while the mortality in that year sum up to as high as 693,933 (8.5\%). In Indonesia itself, there was a reported $27,772(9.3 \%)$ colorectal incidence and 18,398 $(9.5 \%)$ mortality cases in the year of 2012 ; making this type of cancer reign the $4^{\text {th }}$ against other types of cancer in the aspects of both incidence and mortality in that year. ${ }^{2}$ To determine the appropriate treatment for colorectal cancer, stage of cancer is crucial even though other aspects such as type of tumor, patient's age, and patient's degree of health are also taken into consideration. American Joint Committee on Cancer (AJCC) classifies colorectal cancer into 4 distinctive stages along with a $5^{\text {th }}$ "recurrent" stage. ${ }^{3}$ Surgery is mostly implied for colorectal cancer in its early stages; in estimation, 95\% of stage 1 and $65-80 \%$ of stage II colorectal cancers can be cured by surgery. Stage III of colorectal cancer is usually treated firstly by tumor resection with administration of adjuvant chemotherapy such as 5-fluorouracil (5-FU) and leucovorin (LV) such as FOLFOX for 6 months afterwards (Longo et al., 2012). Sometimes, oxaliplatin will also be prescribed in addition to minimize the likelihood of recurrence. ${ }^{4,5}$ Stage IV of colorectal cancer is usually being managed by the combination of therapies which may include surgery, chemotherapy and radiation. Chemotherapy, albeit being a traditional treatment for cancers, possesses undesirable side effects.Chemotherapy drugs namely 5-FU, LV and oxaliplatin often cause neutropenia, diarrhea, vomiting and peripheral neuropathy. ${ }^{6}$ Therefore, new treatments are constantly being developed and researched on so that patients can receive the best treatment possible for their condition. Gallic acid (3,4,5- trihydroxybenzoic acid) is a polyphenolic acid that can be found naturally in plants such as tea leaves, grapes, mango and gall nuts. ${ }^{7}$ Gallic acid has been shown to be a potent inhibitor of fungi, bacteria and some viruses. Further more, according to Morley et al., gallic acid displays chemopreventive activity, which is attributed to its strong apoptosisinducing and antioxidant effects. ${ }^{8}$ Gallic acid is believed to be apoptosis- inducer through the generation of reactive oxygen species (ROS), $\mathrm{Ca}^{+}$ influx as well as calmodulin activation. ${ }^{9}$ Gallic acid's cytotoxic effects on a few cancer cell lines including colon cancer have been established by multiple studies. ${ }^{10,11}$ In 2016, Abd-Rabou and co-workers tested 5 different concentrations of gallic acid which were $100 \mu \mathrm{M}, 50 \mu \mathrm{M}, 25 \mu \mathrm{M}, 12.5 \mu \mathrm{M}, 6.25 \mu \mathrm{M}$ on HCT116 cells and all of the results showed significantly decreased $(P<0.01)$ cell viability; the values being $5.93 \%$, 6.29\%, 7.63\%, 8.19\%, and $22.87 \%$ respectively. ${ }^{12}$ Additionally, gallic acid has been shown to induce apoptosis in cancer cells selectively without doing the same to healthy, normal cells. This terrific finding on the anticancer properties of gallic acid further fuels the interests of researchers to find ways in which the activity could be further enhanced. Owing to the knowledge that gallic acid is a hydrophobic substance, cell membrane permeability is restricted. A study has concluded that an increase in potential cytotoxicity and lipophilicity can be done by modifying the structure of gallic acid by the addition of lipophilic groups. ${ }^{13}$ In the present study, we have done the synthesis of gallic acid derivatives as anti-hepatitis $\mathrm{C}$ virus agents. ${ }^{14}$ Recently, we also done in silico study of gallic acid derivatives as inhibitor of malarial dihydrofolate reductase ${ }^{15}$, as an inhibitors of hepatitis $\mathrm{C}$ virus receptor $\mathrm{NS} \mathrm{B}^{16}$, as an inhibitor of $\mathrm{Bcl}-\mathrm{xl}$ anti-apoptotic protein of breast cancer ${ }^{17}$, and as an inhibitor of BRAF colon cancer ${ }^{18}$.

In this work, as to continue research in developing gallic acid derivatives as an anticancer agent, we focused on the synthesize of 3,4,5-trihydroxy-N-alkyl-benzamides 2-7 (Fig.1), and evaluate its anticancer effect on colon HCT-116 cells by MTT cell proliferation assay.

\section{EXPERIMENTAL}

\section{Design structure of gallic acid derivative}

Six gallic acid derivatives, compound 2-7 (Fig.1) were designed by replacing carboxyl group of gallic acid with a series of corresponding alkylamines to generate 3,4,5-trihydroxy- $\mathrm{N}$-alkyl-benzamides 2-7. Four compounds, namely derivative 2, 3, 4 and 7, were designed to have a linear aliphatic carbon chain in $\mathrm{N}$-alkyl benzamide group, where as compound 5 and 6 were designed to have a branched alphatic carbon chain. 
<smiles>O=C(O)c1cc(O)c(O)c(O)c1</smiles>

Gallic acid (1)<smiles>CNC(=O)c1cc(O)c(O)c(O)c1</smiles>

3,4,5-Trihydroxy- $\mathrm{N}$ methyl-benzamide (2)<smiles>CCNC(=O)c1cc(O)c(O)c(O)c1</smiles>

3,4,5-Trihydroxy- $\mathrm{N}$ ethyl-benzamide (3)<smiles>CCCNC(=O)c1cc(O)c(O)c(O)c1</smiles>

3,4,5-Trihydroxy-Nbutyl-benzamide (4)<smiles>CCC(C)NC(=O)c1cc(O)c(O)c(O)c1</smiles>

3,4,5-Trihydroxy-N-secbutyl-benzamide (5)<smiles>CC(C)(C)NC(=O)c1cc(O)c(O)c(O)c1</smiles>

3,4,5-Trihydroxy-N-tertbutyl-benzamide (6)<smiles>CCCCCCNC(=O)c1cc(O)c(O)c(O)c1</smiles>

3,4,5-Trihydroxy- $N$ hexyl-benzamide (7)

Fig. 1. Structure of gallic acid (1) and desired 3,4,5-trihydroxy-N-alkyl-benzamides 2-7

\section{General experimental method}

All chemical reactions were performed in an oven-dried glassware. Chloroform and methanol in technical grade were purchased from Brataco Indonesia chemical distributor, and were distilled prior to use. Methylamine, ethylamine, butylamine, sec-butylamine, tert-butyl amine, hexylamine and DMF were obtained from Wako Pure Chemical Industries. Gallic acid, doxorubicin, $\mathrm{N}$-(3-dimethylaminopropyl)-n'-ethylcarbodiimide hydrochloride (WSCD.HCl), 1-Hydroxybenzotriazole (HOBt) and N-methyl morpholine (NMM) were purchased from Sigma-Aldrich Chemical Company. Flash column chromatography was carried out using Merck silica gel 60. Reaction and fractions of chromatography were analyzed by Merck precoated silica gel 60 F254 plates. Compounds were visualized by an ultraviolet lamp (254 $\mathrm{nm}$ ) and by staining with ninhydrin (in EtOH). ${ }^{1} \mathrm{H}$ NMR and ${ }^{13} \mathrm{C}$ NMR spectra were recorded on JEOL JNM-ECP500 (500 MHz) spectrometert with tetramethylsilane $\left(\begin{array}{l}\delta \\ 0\end{array}\right)$ and acetone $(\delta 2.05)$ as an internal standard. Mass spectra were measured by JEOL JMS-AX 700 spectrometer. Synthesis and cytotoxicity evaluation of 3,4,5-trihydroxy-N-alkyl-benzamides were carried out in Departement of Medical Chemistry, Faculty of Medicine, University of Indonesia. Structure elucidation of the synthesized 3,4,5-trihydroxy$\mathrm{N}$-alkyl-benzamides were conducted in Graduate School of Materials Science, Nara Institute of
Science and Technology (NAIST), Japan. The tested HCT-116 cancer cells are the culture collection of Anatomical Pathology Department, Faculty of Medicine, University of Indonesia.

\section{General procedure of amidation}

WSCD. hydrochloride (405.0 mg, $3.52 \mathrm{mmol})$ and NMM (0.77 mL, $7.04 \mathrm{mmol})$ was added to a solution of gallic acid $(300 \mathrm{mg}, 1.76 \mathrm{mmol})$, alkylamine (3.52 mmol) and HOBt (357 mg, $2.64 \mathrm{mmol}$ ) in DMF $(5 \mathrm{~mL})$. The mixture was stirred at room temperature for 24 hours. The reaction was diluted by water $(40 \mathrm{~mL})$, and extracted by EtOAc $(3 \times 25 \mathrm{~mL})$. EtOAc extract was collected, further washed with brine $(20 \mathrm{~mL})$, dried over anhydrous $\mathrm{MgSO}_{4}$, filtered and evaporated to give a crude extract. The extract was flash chromatographed on silica gel (gradient elution $\mathrm{CHCl}_{3} / \mathrm{CH}_{3} \mathrm{OH}$ ) to give desired 3,4,5-trihydroxy-Nalkyl-benzamide.

\section{3,4,5-trihydroxy-N-methylbenzamide (2)}

Derivative 2 (248.0 $\mathrm{mg}, 75 \%$ yield) was obtained from flash column chromatography on silica gel of the crude extract (gradient elution 20:1 to $\left.4: 1 \mathrm{CHCl}_{3} / \mathrm{CH}_{3} \mathrm{OH}\right)$ as a brown oil. $\mathrm{R}_{\mathrm{f}} 0.13(5: 1$ $\mathrm{CHCl}_{3} / \mathrm{CH}_{3} \mathrm{OH}$ ); ${ }^{1} \mathrm{HNMR}$ (500 MHz, acetone-d6): 6.94 $(2 \mathrm{H}, \mathrm{s}) ; 2.80(3 \mathrm{H}, \mathrm{d}, \mathrm{J}=4.6 \mathrm{~Hz}) ;{ }^{13} \mathrm{CNMR}(125 \mathrm{MHz}$, acetone-d6): 168.3 (s); 146.3 (s); 136.9 (s); 126.3 (s); 107.3 (d); 26.6 (q); HRMS El+ Calcd for $\mathrm{C}_{8} \mathrm{H}_{9} \mathrm{NO}_{4}$ [M]+: 183.0532, found: 183.0529. 


\section{3,4,5-trihydroxy-N-ethyl benzamide (3)}

Derivative 3 (68.5 $\mathrm{mg}, 20 \%$ yield) was obtained from flash column chromatography on silica gel of the crude extract (gradient elution 25:1 to $\left.7: 1 \mathrm{CHCl}_{3} / \mathrm{CH}_{3} \mathrm{OH}\right)$ as a brown oil. $\mathrm{R}_{\mathrm{f}} 0.31(5: 1$ $\left.\mathrm{CHCl}_{3} / \mathrm{CH}_{3} \mathrm{OH}\right) ;{ }^{1} \mathrm{HNMR}(500 \mathrm{MHz}$, acetone-d6): 7.03 $(2 \mathrm{H}, \mathrm{s})$; 3.41-3.34 (2H, m); 1.15 (3H, t, J = 7.4 Hz); ${ }^{13} \mathrm{CNMR}$ (125 MHz, acetone-d6): 167.8 (s); 146.1 (s); 136.8 (s); 126.5 (s); 107.6 (d); 35.2 (t); 15.1 (q); HRMS El+ Calcd for $\mathrm{C}_{9} \mathrm{H}_{11} \mathrm{NO}_{4}[\mathrm{M}]+: 197.0688$, found: 197.0683 .

\section{3,4,5-trihydroxy-N-butyl benzamide (4)}

Derivative 4 (237.0 mg, 60\% yield) was obtained from flash column chromatography on silica gel of the crude extract (gradient elution 25:1 to $10: 1 \mathrm{CHCl}_{3} / \mathrm{CH}_{3} \mathrm{OH}$ ) as a dark brown solid. Rf 0.38 (5:1 $\left.\mathrm{CHCl}_{3} / \mathrm{CH}_{3} \mathrm{OH}\right) ;{ }^{1} \mathrm{HNMR}(500 \mathrm{MHz}$, acetone-d6): $7.00(2 \mathrm{H}, \mathrm{s})$; 3.37-3.31 (2H, m); 1.59-1.50 (2H, m); 1.41-1.31 (2H, m); $0.90(3 \mathrm{H}, \mathrm{t}, \mathrm{J}=7.8 \mathrm{~Hz}) ;{ }^{13} \mathrm{CNMR}$ (125 MHz, acetone-d6): 167.6 (s); 146.0 (s); 136.6 (s); $126.8(\mathrm{~s}) ; 107.5$ (d); $40.0(\mathrm{t}) ; 32.5(\mathrm{t}) ; 20.7$ (t); 14.1 (q); HRMS El+Calcd for $\mathrm{C}_{11} \mathrm{H}_{15} \mathrm{NO}_{4}[\mathrm{M}]+: 225.1001$, found: 225.0991 .

\section{3,4,5-trihydroxy-N-sec-butyl-benzamide (5)}

Derivative 5 (331.4 $\mathrm{mg}, 84 \%$ yield) was obtained from flash column chromatography on silica gel of the crude extract (gradient elution 25:1 to $\left.9: 1 \mathrm{CHCl}_{3} / \mathrm{CH}_{3} \mathrm{OH}\right)$ as a brown oil. $\mathrm{R}_{\mathrm{f}} 0.44(5: 1$ $\left.\mathrm{CHCl}_{3} / \mathrm{CH}_{3} \mathrm{OH}\right) ;{ }^{1} \mathrm{HNMR}(500 \mathrm{MHz}$, acetone-d6): 6.98 $(2 \mathrm{H}, \mathrm{s}) ; 4.05-3.94(1 \mathrm{H}, \mathrm{m}) ; 1.63-1.47(2 \mathrm{H}, \mathrm{m}) ; 1.16$ $(3 \mathrm{H}, \mathrm{d}, \mathrm{J}=6.9 \mathrm{~Hz}) ; 0.90(3 \mathrm{H}, \mathrm{t}, \mathrm{J}=8.0 \mathrm{~Hz}) ;{ }^{13} \mathrm{CNMR}$ (125 MHz, acetone-d6): 167.1 (s); 145.9 (s); 136.6 (s); 127.0 (s); 107.5 (d); 67.1 (d); 47.6 (t); 20.6 (q); 11.0 (q); HRMS El+ Calcd for $\mathrm{C}_{11} \mathrm{H}_{15} \mathrm{NO}_{4}[\mathrm{M}]+$ : 225.1001, found: 225.0993 .

\section{3,4,5-trihydroxy-N-t-butyl-benzamide (6)}

Derivative $6(69.2 \mathrm{mg}, 18 \%$ yield) was obtained from flash column chromatography on silica gel of the crude extract (gradient elution 25:1 to 8:1 $\left.\mathrm{CHCl}_{3} / \mathrm{CH}_{3} \mathrm{OH}\right)$ as a dark brown oil. $\mathrm{R}_{\mathrm{f}} 0.52$ (5:1 $\left.\mathrm{CHCl}_{3} / \mathrm{CH}_{3} \mathrm{OH}\right) ;{ }^{1} \mathrm{HNMR}(500 \mathrm{MHz}$, acetone-d6): 6.97 $(2 \mathrm{H}, \mathrm{s}) ; 1.28(9 \mathrm{H}, \mathrm{s}) ;{ }^{13} \mathrm{CNMR}(125 \mathrm{MHz}$, acetone-d6): 167.1 (s); 145.9 (s); 136.6 (s); 127.0 (s); 107.5 (d); 42.6 (s); 29.8 (q); HRMS El+ Calcd for $\mathrm{C}_{11} \mathrm{H}_{15} \mathrm{NO}_{4}$ [M]+: 225.1001, found: 225.0994 .

\section{3,4,5-trihydroxy-N-hexyl-benzamide (7)}

Derivative 7 (357.0 $\mathrm{mg}, 80 \%$ yield) was obtained from flash column chromatography on silica gel of the crude extract (gradient elution 25:1 to 5:1 $\left.\mathrm{CHCl}_{3} / \mathrm{CH}_{3} \mathrm{OH}\right)$ as a yellow solid. $\mathrm{R}_{\mathrm{f}} 0.33\left(5: 1 \mathrm{CHCl}_{3} /\right.$ $\mathrm{CH}_{3} \mathrm{OH}$ ); ${ }^{1} \mathrm{HNMR}(500 \mathrm{MHz}$, acetone-d6): 6.99(2H, s); $3.59(2 \mathrm{H}, \mathrm{t}, \mathrm{J}=5.2 \mathrm{~Hz}) ; 1.59-1.52(2 \mathrm{H}, \mathrm{m}) ; 1.37-$ $1.23(4 \mathrm{H}, \mathrm{m}) ; 0.85(3 \mathrm{H}, \mathrm{t}, \mathrm{J}=8.2 \mathrm{~Hz}) ;{ }^{13} \mathrm{CNMR}(125$ $\mathrm{MHz}$, acetone-d6): 167.6 (s); 146.0 (s); 136.7 (s); 126.7 (s); 107.5 (d); 66.9 (t); 56.0 (t); 32.3 (t); 27.3 (t); $23.2(\mathrm{t}) ; 14.2(\mathrm{q})$; HRMS El+ Calcd for $\mathrm{C}_{11} \mathrm{H}_{15} \mathrm{NO}_{4}$ [M]+: 253.1314, found: 253.1306 .

\section{Cytotoxicity Evaluation}

Suspension of cells $(100 \mu \mathrm{L})(5000$ cells. well) of HCT-116 was dispensed to a 96-well plate. The plate was pre-incubated for $24 \mathrm{~h}$ in a humidified incubator containing $5 \% \mathrm{CO}_{2}$ at $37^{\circ} \mathrm{C}$. The various concentration of tested samples $(0-200 \mathrm{mM})$ were added into the culture media in the plate. The plate was incubated for an appropriate lenght of time (72 $\mathrm{h}$ ) in the incubator. $10 \mu \mathrm{L}$ of MTT solution was then added to each well of the plate which was subsequently incubated for 1-4 $\mathrm{h}$ in the incubator. This mixture was then measured for absorbance by Elisa reader at $630 \mathrm{~nm}$. This procedure was triplicated for each plate. $I_{50}$ value was determined using probit method by plotting the concentration of the sample against percentage of living cells.

\section{RESULT AND DISCUSSION}

\section{Synthesis of gallic acid derivatives} (3,4,5-trihydroxy- $\mathrm{N}$-alkyl benzamide)

Synthetic pathway of 3,4,5-trihydroxy-Nalkyl-benzamide 2-7 is summarized in Fig. 2. As shown, amidation of gallic acid (1) with methylamine, ethylamine, butylamine, sec-butylamine, tert-butyl amine, and hexylamine using a combination of WSCD. $\mathrm{HCl} / \mathrm{HOBt}$ in the presence of basic NMMafforded the corresponding 3,4,5-trihydroxy-N-alkyl-benzamides, which are 3,4,5-trihydroxy- $\mathrm{N}$ - methyl-benzamide (2), 3,4,5-tri-hydroxy-N-ethyl-benzamide (3), 3,4,5-trihydroxy-N-butyl-benzamide (4), 3,4,5-tri-hydroxy- $\mathrm{N}$ sec-butyl-benzamide(5),3,4,5-trihydroxy-N-tert-butylbenzamide (6) and 3,4,5-trihydroxy-N-hexyl-benzamide (7) with a yield ranging from $18 \%$ to $84 \%$. 
Anticancer effect of 3,4,5-trihydroxy-N-alkylbenzamides

Anticancer activity of 3,4,5-trihydroxy-Nalkyl-benzamides against colon HCT-116 cellsis displayed in Table 1. Half maximal inhibitory concentration $\left(\mathrm{IC}_{50}\right)$ value is utilized to express

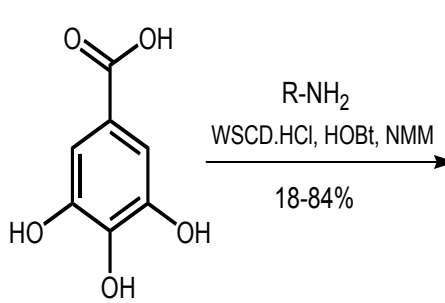

Gallic acid (1)<smiles>[R]NC(=O)c1cc(O)c(O)c(O)c1</smiles>

3,4,5-Trihydroxy- $N$ alkyl-benzamide anticancer activity of the derivatives. The lower $\mathrm{IC}_{50}$ value the higher anticancer activity. As shown in Table 1, compared to gallic acid $\left(\mathrm{IC}_{50}: 0.05 \mu \mathrm{M}\right)$ and doxorubicine $\left(\mathrm{IC}_{50}: 0.001 \mu \mathrm{M}\right)$, all these six synthesized derivatives showed a lower anticancer effect on HCT 116 cells.

3,4,5-trihydroxy- $\mathrm{N}$-methyl-benzamide (2), $\mathrm{R}=-\mathrm{CH}_{3}$ 3,4,5-trihydroxy- $\mathrm{N}$-ethyl-benzamide (3), $\mathrm{R}=-\mathrm{CH}_{2} \mathrm{CH}_{3}$ 3,4,5-trihydroxy- $\mathrm{N}$-butyl-benzamide $\quad(4), \mathrm{R}=-\left(\mathrm{CH}_{2}\right)_{3} \mathrm{CH}_{3}$ 3,4,5-trihydroxy- $\mathrm{N}$-sec-butyl-benzamide (5), $\mathrm{R}=-\mathrm{CH}\left(\mathrm{CH}_{3}\right) \mathrm{CH}_{2} \mathrm{CH}_{3}$ 3,4,5-trihydroxy-N-tert-butyl-benzamide (6), $\mathrm{R}=-\mathrm{C}\left(\mathrm{CH}_{3}\right)_{3}$ 3,4,5-trihydroxy- $\mathrm{N}$-hexyl-benzamide $\quad(7), \mathrm{R}=-\left(\mathrm{CH}_{2}\right)_{5} \mathrm{CH}_{3}$

Fig. 2. Synthesis of 3,4,5-trihydroxy-N-alkyl-benzamides 2-7

Except for 3,4,5-trihydroxy-N-butylbenzamide (4), there is a visible trend of decreasing $\mathrm{IC}_{50}$ value and/or increasing anticancer activity from 3,4,5-trihydroxy-N-methyl-benzamide2 (IC ${ }_{50}: 2.43$ $\mu \mathrm{M}), 3,4,5$-trihydroxy-N-ethyl-benzamide3 $\left(\mathrm{IC}_{50}: 1.64\right.$ $\mu \mathrm{M})$, and 3,4,5-trihydroxy- $\mathrm{N}$-hexyl-benzamide7( $\mathrm{IC}_{50}$ : $0.07 \mu \mathrm{M})$. This signifies that in general, 3,4,5trihydroxy-N-alkyl-benzamide with longer hydro-phobic carbon chain of -N-alkyl-benzamide group, possess a higher anticancer activity.

However, the fact that all six compounds of 3,4,5-trihydroxy-N-alkyl-benzamides have higher $\mathrm{IC}_{50}$ value than original gallic acid, might suggest that although carboxyl group is classified as being hydrophilic, they are crucial for anti- colorectal cancer activity. Derivative 3,4,5-trihydroxy-N-ethylbenzamide (3), shows improved anticancer effect on HCT-116 cells when it compared to 3,4,5-trihydroxy$\mathrm{N}$-methyl-benzamide (2), which implies that an addition of methylene $\left(-\mathrm{CH}_{2}\right)$ group in 3,4,5-trihydroxy$\mathrm{N}$-ethyl-benzamide (3), increases its hydrophobicity. Compared to 3,4,5-trihydroxy-N-butyl-benzamide4 $\left(\mathrm{IC}_{50}: 3.56 \mu \mathrm{M}\right)$ that has linear aliphatic carbon chain in -N-alkyl-benzamide group,3,4,5-trihydroxy$\mathrm{N}$-sec-butyl-benzamide5 $\left(\mathrm{IC}_{50}: 1.34 \mu \mathrm{M}\right)$ and 3,4,5-trihydroxy-N-tert-butyl-benzamide $6\left(\mathrm{IC}_{50}: 0.16\right.$ $\mu \mathrm{M})$ which have a branched aliphatic carbon chain, showed higher anticancer activity against HCT-116 cellss. Moreover, Among all the six synthesized 3,4,5-trihydroxy-N-alkyl-benzamides, derivative 3,4,5-trihydroxy-N-hexyl-benzamide (7) with $\mathrm{IC}_{50}$ of $0.07 \mu \mathrm{M}$, shows the greatest potential to be developed as an anti- colorectal cancer agent. Additionally, further studies examining the anti-colorectal cancer properties of 3,4,5-trihydroxy$\mathrm{N}$-heptyl-benzamide and 3,4,5-trihydroxy-N-octylbenzamide that possess a longer aliphatic carbon chain than 3,4,5-trihydroxy-N-hexyl-benzamide (7) needs to be conducted.

Table 1: Anticancer activity $\left(\mathrm{IC}_{50}\right.$ in $\left.\mu \mathrm{M}\right)$ of 3,4,5-trihydroxy-N-alkyl-benzamides 2-7, gallic acid (1), and doxorubicine against colon HCT-116 cells

\begin{tabular}{|c|c|}
\hline Compound & Cytotoxicity $\left(\mathrm{IC}_{50}, \mu \mathrm{M}\right)$ \\
\hline Gallic acid (1) & 0.05 \\
\hline 3,4,5-trihydroxy-N-methyl-benzamide (2) & 2.43 \\
\hline 3,4,5-trihydroxy-N-ethyl-benzamide & 1.64 \\
\hline 3,4,5-trihydroxy-N-butyl-benzamide & 3.56 \\
\hline 3,4,5-trihydroxy-N-sec-butyl-benzamide (5) & 1.34 \\
\hline 3,4,5-trihydroxy-N-tert-butyl-benzamide (6) & 0.16 \\
\hline 3,4,5-trihydroxy-N-hexyl-benzamide & 0.07 \\
\hline Doxorubicine & 0.01 \\
\hline
\end{tabular}




\section{CONCLUSION}

Six compounds of 3,4,5-trihydroxy-Nalkyl-benzamides have been synthesized through amidation of gallic acid with the corresponding alkylamines. Among six synthesized derivatives, 3,4,5-trihydroxy-N-hexyl-benzamide (7) showed the greatest anticancer effect on HCT-116 cells.

\section{ACKNOWLEDGEMENT}

We wish to express our gratitute to
Directorate of Research and Public Service (DRPM) and Faculty of Medicine, University of Indonesia for the PITTA (Publikasi Internasional Terindeks untuk Tugas Akhir Mahasiswa) research grant Fiscal year 2017, and to the Graduate School of Materials Science, Nara Institute of Science and Technology (NAIST), Japan, for International Research Collaboration Program (NAIST Global Initiative Program).

\section{REFERENCES}

1. Ferlay, J.; Shin, H.R.; Bray, F.; Forman, D. Mathers, C.; Parkin, D.M. Int. J. Cancer., 2010, 127, 2893-2917.

2. WHO. GLOBOCAN 2012: Estimated cancer incidence, mortality and prevalence worldwide in 2012[Internet]. 2012[updated 2014 Feb 14; cited 2017 Aug 15]. Available from:http:// globocan.iarc.fr/Pages/fact_sheets_ population.aspx

3. Mishra, J.; Dromund, J.; Quazi, S.H.; Karanki, S.S.; Shaw, J.J.; Chen, B. Crit. Rev. Oncol. Hematol., 2013, 86, 232-250.

4. Longo, D.L.; Kasper, D.L.; Jameson, J.L.; Fauci, A.S.; Hauser, S.L.; Loscalzo, J. Harrison's Principles of Internal Medicine. 18thed. New York: McGraw-Hill. 2012, 537538.

5. Gramont, A.D.; Figer, A.; Seymour, M.; Homerin, M.; Hmissi, A.; Cassidy, J. J. Clin. Oncol., 2000, 18, 2938-2947.

6. André, T.; Boni, C.; Mounedji-Boudiaf, L.; Navarro, M.; Tabernero, J.; Hickish, T. N Engl. J. Med., 2004, 350, 2343-2351.

7. Yoon, C.H.; Chung, S.J.; Lee, S.W.; Park, Y.B.; Lee, S.K.; Park, M.C. Joint Bone Spine., 2013, 80, 274-279.

8. Silva, I.C.; Polaquini, C.R.; Regasini, L.O.; Ferreira, H.; Pavan, F.R. Food Chem. Toxicol., 2017, 105, 300-307.
9. Filipiak, K.; Hidalgo, M.; Silvan, J.M.; Fabre, B.; Carbajo, R.J.; Pineda-Lucena, A. Food Funct., 2014, 5, 381-389.

10. Esteves, M.; Siquet, C.; Gaspar, A.; Rio, V.; Sousa, J.B.; Reis, S. Arch. Pharm. Chem. Life. Sci., 2008, 341, 164-173.

11. Khaledi, H.; Alhadi, A.A.;Yehye, W.A.; Ali, H.M.; Abdulla, M.A.; Hassandarvish P. Arch. Pharm. Chem. Life Sci., 2011, 344, 703-709.

12. Abd-Rabou, A.A.; Shalby, A.B.; Ahmed, H.H. Int. J. Pharm. Bio. Sci., 2016, 7, 584-592.

13. Dorothea, M.; Arsianti, A.; Liwang, F.; Christian, H.; Panjaitan, H.P. Ann. Oncol., 2016, 17 (7), 523-532.

14. Arsianti, A.; Aoki-Utsubo, C.; Fadilah; Bahtiar, A.; Apriyanto, D.R.; Dwira, S.; Pradisty, N.A.; Tanimoto, H.; Kakiuchi, K.; Sudarmono, P.; Hotta, H.; Paramita, R.I.; Erlina, L. Asian J. Pharm. Clin. Res., 2017, 10, 164-167.

15. Arsianti, A.; Astuty, H.; Fadilah; Bahtiar, A.; Tanimoto, H.; Kakiuchi, K. Asian J. Pharm. Clin. Res., 2017, 10, 330-334.

16. Arsianti, A.; Fadilah; Bahtiar, A.; Dwira, S.; Apriyanto, D.R.; Paramita, R.I. Int. J. Chemtech Res., 2017, 10, 111-117.

17. Paramita, R.I.; Arsianti, A.; Radji, M. Int. J. Chemtech Res., 2017, 10, 348-355.

18. Humaedi, A.; Arsianti, A.; Radji M. Int. J. Chemtech Res., 2017, 10(1), 310-315. 